\title{
A Socioeconomic and Historical Interpretation of the Place of Social Sciences, Arts, and Humanities in the Saudi HE Ecosystem: Job Market Implications
}

\author{
Zachary Y Mngo ${ }^{1, *}$, Jörg Muth ${ }^{2}$ \\ ${ }^{1}$ School of Education and Social Sciences, Department of Education, Oakwood University, Huntsville, 35896, Alabama, United States \\ ${ }^{2}$ Department of Leadership and Management, Baltic Defense College, 51010 Tartu, Estonia
}

Received June15, 2021; Revised July 14, 2021; Accepted August 22, 2021

\section{Cite This Paper in the following Citation Styles}

(a): [1] Zachary Y Mngo, Jörg Muth, "A Socioeconomic and Historical Interpretation of the Place of Social Sciences, Arts, and Humanities in the Saudi HE Ecosystem: Job Market Implications," Universal Journal of Educational Research, Vol. 9, No. 9, pp. 1676 - 1688, 2021. DOI: 10.13189/ujer.2021.090908.

(b): Zachary Y Mngo, Jörg Muth (2021). A Socioeconomic and Historical Interpretation of the Place of Social Sciences, Arts, and Humanities in the Saudi HE Ecosystem: Job Market Implications. Universal Journal of Educational Research, 9(9), 1676 - 1688. DOI: 10.13189/ujer.2021.090908.

Copyright $\bigcirc 2021$ by authors, all rights reserved. Authors agree that this article remains permanently open access under the terms of the Creative Commons Attribution License 4.0 International License

\begin{abstract}
The article reviews the sociocultural and historical development of the higher education system in the Kingdom of Saudi Arabia with focus on its impacts on the current makeup of bachelor's degrees offered by universities in the Kingdom. Literature and analysis of data from forty-six tertiary education websites indicate that while there is an abundance of programs in Science, Technology, Engineering, Math (STEM) and business, there is a significant paucity of degrees in the Social Sciences, Arts, and Humanities (SSAH). The authors argue that the Kingdom's official development plan, Vision 2030, requires a more precise appendage when it comes to higher education. An analysis of data on bachelor's degrees reveals that both the degree landscape and students' choices of college majors favor certain STEM and business programs. STEM and business programs have been historically promoted by the traditional government policy emanating from the need to prepare Saudi students to obtain jobs in the petrochemical industry. This article posits that the excessive promotion of some STEM and business programs has engendered the neglect of the social sciences, arts, and humanities programs that play an equally vital role in students' holistic educational development. It further predicates that the paucity of degrees in these STEM fields would undermine the government's desire, to diversify an economy that has been heavily dependent on oil for more
\end{abstract}

than half a century as expressed in Vision 2030.

Keywords Higher Education, Economy, Diversification, Sustainability, Job Market, Social Sciences, Arts, Humanities, Employability

\section{Introduction}

Saudi Arabia is in many ways unique due to its size and its political and economic power in the Gulf region. It possesses some of the largest oil reserves in the world and hosts the seat of the holy sites of one of the world's most popular religions, Islam. The country is not only a leading petroleum producer and founding member of Organization of Petroleum Exporting Countries (OPEC), but it also has the world's largest oil company, Saudi ARAMCO. The country's long stretch of prosperity following the discovery of its immense oil reserves in the 1930s is now being tested by growing unemployment [37]. Like many oil-based and oil-rich economies, the country has recently begun to reevaluate its educational and economic policies and overall strategic planning.

Economic diversification has gained a renewed sense of urgency as the country has experienced economic slowdowns caused largely by unstable crude oil prices. 
The country's Vision 2030 is the most visible government initiative intended to reduce dependence on oil through economic diversifying and heavy investments in public service sectors such as education, health, infrastructure, recreation, and tourism [35]. The current unemployment rate of about $8.22 \%$ is the highest the Kingdom has seen in decades [38]. These unemployment statistics make the Vision 2030 economic broadening goals even more appealing. Considering that education, particularly higher education, plays a crucial rule in economic change, it is evident that the success of any plans to diversify an economy must begin with the diversification of skills needed by the shifting economy. Training programs in tertiary education institutions must reflect the needs of a diversified workforce.

This article provides a concise overview of the history of education in the country and examines the impact of the sociocultural and economic elements on its higher education policies, practice, and degree offerings. Further, it discusses the current landscape of Saudi Arabia's higher education through the evaluation of data from higher educational websites that contains an overview of the bachelor's degrees that are offered in the country and how they correlate with the needs of society particularly one attempting to expand by moving away from complete dependence on the petrochemical industry.

A review of the literature reveals that the development of higher education in the country has been significantly impacted by the oil industry. The discovery of oil in 1933 prompted the subsequent building of an education system designed to support the needs of oil production and the petrochemical industry. This explains why Science, Technology, Engineering, and Mathematics programs (STEM) and business programs occupy a prominent place in the Saudi higher education system [29]. There is no doubt that STEM and business programs should be highly valued by any society. It must be said that the trend towards devaluing arts and humanities programs in the face growing preference for STEM is not a uniquely Saudi problem. The United States tertiary educational institutions have experienced significant declines in humanities major [32]. The difference with the Saudi situation lies in the fact the arts and humanities have never been popular in first place. It is without gainsay that an economic revitalization and expansion effort that does not consider the important role of careers in Social Sciences, Arts, and Humanities (SSAH) will likely not be as successful as anticipated. The literature suggests that excessive focus on STEM and business programs in Saudi higher educational institutions led to the undervaluing of SSAH programs [28]. When degree and training programs intended to furnish certain sectors of the economy with a skilled labor force are overlooked, there is neither interest nor qualified manpower in the workforce to occupy a variety of jobs.

The Saudi government's yearning to diversify its economy has been perceptible since the 1970s, but the concrete efforts toward diversification have intensified in recent years because of the downturns in the country's economy. According to Euchi and Al-Tit [14], recent Saudi diversification efforts have focused on investment in education, entrepreneurship, international tourism, and oil production. The education component of this effort is flawed the limited number of degrees in and graduates from the social sciences, arts, and humanities programs in Saudi colleges and universities. Though STEM programs are designed to drive the technological and scientific innovations of the future, it would be erroneous to ignore the important role of SSAH jobs in a diversified economy as well as to other career professions. Social sciences and humanities programs and general education with a strong social sciences and humanities component produce intellectuals that think critically, solve problems, communicate effectively, make decisions, and adapt to change.

Education continues to carry lion's share of Saudi Arabia's government budget. However, investments in educations must not limited to laudable initiatives such as the Future Gate-a project implemented by Tatweer Educational Technologies (TETCO) by ushering in smart classrooms and digital education management system in Saudi Arabia [37]. Investments in education would be more profitable if SSAH degrees and jobs are valued and promoted by both the society and the higher education (HE) system. This approach would guarantee education and workforce training goals aligned completely with the desire to diversify the economy by 2030 . Research on workforce development is one of the major innovations of post-secondary education, especially in community colleges. It reveals a new workforce development approach to curriculum development. Jacobs and Worth [18] purport that the essential features of the approach include developing curriculum that is driven by the needs of local industry and course delivery systems that are sufficiently flexible to meet the diverse needs of students and industry. The significant scarcity of Saudi graduates and the dominance of expatriates in SSAH jobs indicate that the Saudi government and higher education leadership have not always considered the needs of local industry in the development and implementation of education and training policies. Saudi higher educational institutions, for example, continue use a substantial number of expatriates in positions ranging from office managers, faculty, and deans. This is exacerbated by the fact that there is a disproportionately high number of Saudi students studying abroad on government scholarships major in STEM programs [37].

The mere creation of SSAH programs in Saudi Universities would not be enough to increase trained nationals in the fields. Sensitizing young Saudis and their families that obtaining a STEM or business degree and career is not the only measure of success. For this 
initiative to be meaningful, government must invest in creation and promotion of prestigious and high-paying jobs in sectors other than petrochemical such as professors, hospitality professionals, and archeologists. Weinberger and Nestor [36] argue that diversification works when it is driven by the demands of the job markets.

This paper reviews data on undergraduate degree programs in Saudi universities, including literature associated with Saudi attitudes on STEM and business programs and the socioeconomically influenced tendency to underrate majors in social science, arts, and humanities (SSAH) by most higher education stakeholders.

\subsection{Purpose of the Study}

This study sought to investigate the level of representation of Social Sciences, Arts, and Humanities bachelor's degree programs in the Saudi higher education ecosystem. The researchers had observed in their university of employment and surrounding universities in the Eastern Province of Saudi Arabia that there was a significant paucity of such programs. Since this initial observation was anecdotal and based on one region of the country, a nationwide study was conducted to understand the extent to the phenomenon in Saudi colleges and universities. Interest in the study was further fueled by one of the goals of Saudi government's Vision 2030 which aims to gradually move the country's economy from dependency on the petrochemical industry through the diversification [35]. As a result, the study sought to understand the degree to which the Saudi higher education system is set up to support the government in its economy diversification efforts.

The initial analysis was based on a private university in the Eastern Province of the country. Three hypotheses emerged. First, there is a significant deficiency in the diversification of degree offerings in Saudi colleges and universities. Second, STEM and business programs are disproportionately represented while social sciences, arts, and humanities programs are disproportionately underrated. Third, the paucity of SSAH programs offerings would be counterproductive to government initiatives aimed at promoting the diversification of the workforce to fill positions in a modern job market that needs skills and talents in professions other than engineering and business.

To verify the authenticity of our hypothesis, further investigation was guided by the following research questions:

1. Is there a significant imbalance in the distribution of degrees in Saudi higher educational institutions in favor of the STEM and business majors?

2. Are private institutions more likely to invest less in social sciences, arts, and humanities (SSAH) programs than public institutions?
3. Do socioeconomic and historical factors affect the Saudi students and higher educational institutions' attitudes toward social sciences, arts, and humanities

\section{Materials and Method}

An extensive review of literature on Saudi higher education and its interconnectedness with country's culture, history, and economy as well as the documentation of data on BA degree offerings in select public and private colleges and universities was employed which constituted the main source of data for this review study. Literature on the history of Saudi higher education is analyzed to understand the root causes for the limited interest in the social sciences, arts, and humanities programs and the excessive interest by stakeholders in the promotion of some STEM and business programs.

Data on the programs collected from the websites was grouped into three major areas of specialization, namely (1) STEM, (2) Business, and (3) Social Sciences, Arts and Humanities. In this study STEM fields include mathematics, natural sciences, medical sciences, engineering, and computer and information sciences. This demarcation breaks from the National Science Foundation's definition of STEM which considers behavioral sciences such as psychology, economics, sociology, and political as STEM [24]. Instead, these behavioral sciences programs are considered as social sciences. Some business degrees such as Management Information Systems could also be considered STEM degrees if assessed by their contents but were considered in this study as business degrees as classified by the institutions.

Education, Law, and Islamic Studies were not considered for this study because of the uniqueness of the programs' contents. Many programs in education and law had aspects of Islamic education and the Sharia law that we believed made their inclusion in the study sample inappropriate. Another degree excluded from our Social Sciences, Arts, and Humanities database are Arabic Language and the multitude of theological degrees in Islamic Studies. These degrees were not considered because Saudi employers accord little economic value and also because there is already a significant number of unemployed graduates in the field [20].

\subsection{Study Population and Sample}

The choice and location of the colleges and universities included in the study was purposeful. Saudi Arabia with a population of about 34.27 million people is divided into thirteen large administrative units called provinces. To collect a representative sample, we sought to include as many private colleges and universities in the study as possible considering that most tertiary education 
institutions are government owned. In the same vein, the sample included at least tertiary education institution from each of the thirteen provinces/regions of the country (see Table 1). To better understand the socioeconomic and historical factors that have shaped the Saudi higher education landscape, 46 universities and colleges that offer bachelor's degrees were assessed.

Table 1. HE Institutions Sampled by Region

\begin{tabular}{cccc}
\hline Province & $\begin{array}{c}\text { \# HE Institutions } \\
\text { Sampled }\end{array}$ & $\begin{array}{c}\text { \# of } \\
\text { Private }\end{array}$ & \# of Public \\
\hline East & 8 & 2 & 6 \\
Riyadh & 13 & 6 & 7 \\
Mecca & 7 & 3 & 4 \\
Medina & 6 & 2 & 5 \\
Asir & 2 & 1 & 1 \\
Hail & 1 & 0 & 1 \\
Tabuk & 2 & 1 & 1 \\
Qasim & 2 & 1 & 1 \\
Najran & 1 & 0 & 1 \\
Jizan & 1 & 0 & 1 \\
Northern & 1 & 0 & 1 \\
Borders & 1 & 0 & 1 \\
Bahah & 1 & 0 & 1 \\
Al Jawf & $\mathbf{4 6}$ & $\mathbf{1 6}$ & $\mathbf{3 0}$ \\
\hline Total & & &
\end{tabular}

Categorization of majors was done based on the academic departments hosting them in the Saudi educational environment. For example, Interior Design is usually found in arts departments while in Saudi Arabia it is taught as an engineering field and therefore usually to be found in the engineering department. The Saudi Ministry of Education tries to follow the UNESCO Standard Classification of Education programs when publishing their statistics. However, total compliance is not in all cases possible because of the specifics of the national educational system [34].

\section{Review of Literature}

In this section we explore literature from empirical studies as well as news outlets that have investigated the issues related to unemployment and higher education in Saudi Arabia. The section is divided into three main parts, oil discovery and implication for Saudi Education, the adoption of the American system of education, and a historical overview of Saudi HE penchant for some STEM Programs. The review of these areas helps to provide both a historical and sociocultural context that clarifies why the society and higher educational system has enabled certain condescending attitudes toward studies and jobs in fields other than STEM and business fields. It also serves to highlight what is at stake with the government's mission to move the economy from oil dependency to complete diversification and sustainability if nothing is done to change attitudes.

\subsection{Oil Discovery and Implication for Saudi Education}

At the start of the $20^{\text {th }}$ century, Abdulaziz Ibn Saud united the majority of the Arabian Peninsula with a combination of successful tribal politics and military conquest. After three decades of conquering, he declared himself King of Saudi Arabia, a vast country of more than 2.15 million square kilometers, the twelfth largest in the world at the time. However, Saudi Arabia was little known to the rest of the world except as a premier producer of dates; a position that the Kingdom still holds today, but which became overshadowed by massive wealth from the petrochemical industry following the discovery of immense oil reserves [41]. Things changed in 1933 when oil was discovered by American engineers. To the chagrin of the British, King Abdulaziz signed an exclusive oil development treaty with the Americans. In 1945 President Franklin Delano Roosevelt met the king and a political treaty was signed bringing Saudi Arabia formally on the side of the Allies in World War II [41].

The influx of wealth through the oil revenue proved to be overwhelming and a new chapter in the life of the country. It is believed by reporters of Saudi history that the overwhelming influx of oil wealth is the main reason why education took a back seat in the early years of Saudi Arabia as a country [29]. Some biographers claimed that King Abdulaziz, who reigned from 1932 to 1953, had a great interest in education. Also, the Saudi education Ministries have documented that formal education in the country was established in the 1930s following the creation of a Directorate of Knowledge between 1925 and 1926. Despite of the documented claims, there is little evidence of an organized primary school system before 1945 [21].

\subsection{The Adoption of the American System of Education}

According to researchers, Saudi education system was fashioned after the American system of K-12 and higher education even though the rigors associated with teacher training and certification in the American system are not fully applied. At about the age of six years old, children start primary education which lasts six years. The junior high, as well as the high school education, last another three years each and thus any young Saudi is supposed to have attended school for twelve years. Considering that most high school graduates are not prepared enough for college in crucial disciplines such as mathematics and English which is gradually becoming the main language of instruction, several colleges and universities require at least one year of preparatory school before the young Saudis are allowed to enter the university [10,11]. In recent years, the Saudi government has introduced more 
stringent requirements for teacher training, including mandatory certification for teachers to improve the quality of secondary education [7].

The Saudi Government established a system of community colleges and vocational schools in all the provinces where students can attain an Associate Degree. But these post K-12 educational institutions, unlike American community colleges exclusively offer technological programs.

\subsection{Historical Overview of the Saudi HE Penchant for Some STEM and Business Program}

King Saud University was the first university in Saudi Arabia in 1957. This University started a pattern that the Saudi higher education system has followed to date. It offered a variety of engineering, computer, and business degrees and very little else. It is not surprising that the well-known King Saud University and many other older colleges and universities never started offering a few full-fledged humanities degrees until recently.

Islamic University in Medina was the second university founded in 196. It continued to prioritize engineering, computer science, and business administration except for Islamic studies. Considering the huge size of Saudi Arabia, it made sense to space out universities in highly populated centers. The government policy of making education accessible to all Saudis led to creation of new universities in the Eastern Province [29].

Until the turn of the millennium, Saudi Arabia only had a dozen universities. The pace of the growth of universities accelerated with the opening of the first private institution of higher learning in 1999 [29]. Prince Sultan University started the trend and today Saudi Arabia has 16 private universities which constitute nearly a quarter of the university landscape. Again, as was the case for several years with public universities, private universities continued to prioritize some STEM-related programs while pay little attention to the programs in social sciences, arts, and humanities.

Alamri posits that the educational sector gained a front seat in government developmental initiatives from 2005 to 2015 during the reign of Abdullah bin Abdulaziz Al Saud (2005-2015) who understood the need to prioritize the training of young Saudis against the backdrop of an increasing influx of expatriates in Saudi educational institutions and petrochemical industries [9]. This king had shown a penchant for reform when he became crown prince earlier in 1982. Prior to his reign, mostly young Saudis from wealthy families sent their children to study abroad. King Abdullah established a scholarship program for young Saudis, paying their tuition and living costs for a maximum of four years in foreign universities [9]. According to UNESCO the number of Saudi students studying abroad rose from 10,139 in 1998 to 139,019 in 2017 [37]. The Saudi Ministry of Education reported similar enrollment statistics earlier in 2016, stating that the country is the fifth in the ranking of countries with most students studying outside of their home country [22]. Despite the huge number of students on scholarships in schools abroad, there was large disparity in the distribution of the scholarships in the fields of business, engineering, and computer science. According to Clark, nearly $46 \%$ of the young people studied in these fields, while 27\% are enrolled in intensive English programs in preparation for transition into the STEM programs [12].

In April 2016, Saudi Arabia launched Vision 2030, an ambitions reform plan designed to move the economy away from its current dependency on oil [35]. Most of plan focuses on structural economic reforms and Human Capital Development Program. The plan indicates that government is fully aware of some educational reforms that must be done to ensure its successful implementation. The plan includes the following statement:

The Human Capital Development Vision Realization Program aims to improve the outputs of the education and training system at all stages from early education to continuous education and provide training to reach the international levels through education, rehabilitation and training programs that keep abreast of modern times and requirements and are in line with the needs of development and the local and global labor market in partnership with all relevant parties locally and internationally. The program also contributes to the development of all components of the education and training system, including teachers, trainers, faculty members, governance, evaluation systems, quality, curricula, educational and vocational paths, and training environment for all stages of education and training to cope with modern and innovative trends in the fields of education and training. The program will be based on the Islamic, educational, social and professional foundations."

Several decades after the creation of the first Saudi university, it remains evident that the education component of the Saudi Vision 2030 development plan has a laser focus on some STEM programs [35]. The 2018 goal of the plan was the introduction of "university technical programs" like Artificial Intelligence and Cyber Security. The "Increase Employment Section", section 4.1 of the plan seeks to "...develop human capital in line with labor market needs" and subsection 4.1.6. emphasizes the “...alignment of educational outputs with labor market needs" [35].

From every indication, the educational initiative of the plan is intended to meet the demands of a broader job market. However, the plan is built on the inaccurate premise that a diversified job market would mean creating new jobs only in STEM-related professions. Diversified economies need jobs and professionals in diverse fields, including jobs in social sciences, arts, and humanities. 
Like many societies, the Saudi labor market needs are vast and complex, yet there is little degree diversity among graduates of Saudi colleges and universities. This state of affairs has not helped with issue of increasing unemployment rates. While the official unemployment rate now stands at around $8.22 \%$, things are far worse in female unemployment rates which is at $22.56 \%$ [38]. A weak private sector could explain why most students and parents believe only in STEM education that leads to government jobs. Most students seem to believe that the only way to a bright career is training in an area that leads to employment in the government-owned petrochemical industries [33].

A major component of Vision 2030 is the privatization of businesses and programs [35]. Privatization and a strong private sector will only be possible if the mentalities about employment change. Considering that $70 \%$ to $80 \%$ of all businesses are still government-owned, it is not surprising that current college graduates still have the same age-old traditional attitude, as prior generations with the expectation of a cozy job in the Saudi government [3]. Several reports have confirmed that the infatuated desire for government jobs among youth is a regional problem affecting most of the Gulf Cooperation Council countries. These reports, based on national and regional surveys indicate that more than $70 \%$ of youths in Saudi Arabia and other gulf countries prefer government jobs, mostly in the oil sector [33]. It is obvious in this circumstance that the citizens' employment dreams are detrimental to those of the government because while the government is pursuing economic stability by diversifying the job, promoting private initiative, and reducing overreliance on the petrochemical industry, the Saudi youth are still infatuated with desire to work only for the government and its subsidiaries. The limited scope of degree availability in arts, humanities, and social sciences as well as the lack of robust governmental incentives may explain why fewer students are interested in the non-STEM fields. The literature clearly indicates that in order to be successful in its efforts to diversify the economy, the Saudi government must make professions in fields other than STEM attractive through targeted investments in HE programs and jobs in fields need expertise in social sciences, arts, and humanities.

\subsection{Limitations}

The data analyzed did not include colleges and universities that offered only master's degrees, military universities, and universities that specialized in medical fields or aviation. Institutions with impervious and inaccessible websites were also excluded. In addition, some websites were not current and had not been updated since 2010. These drawbacks made it difficult to know the exact number of degrees offered in some of the institutions assessed. Despite these limitations, the findings of this study depict a reliable assessment of the academic distribution of programs in the Saudi HE landscape. The findings largely corroborate the literature explored in this study.

\section{Results}

Forty-six colleges and universities were sampled, 30 public and 16 private institutions. The 30 public institutions represented $62.23 \%$ of the study sample while private institutions represented $34.79 \%$ of sample.

Data revealed that the Saudi tertiary education map displays a highly disproportionate representation of degrees in three clusters programs-(1) STEM, (2) Business, and (3) Social Sciences, Arts and Humanities (SSAH). There was a significant underrepresentation of programs in Social Sciences, Arts, and Humanities. While $61.27 \%$ of programs were STEM and $24.78 \%$ business, only $13.95 \%$ of the programs were in the social sciences, arts, and humanities fields (see Table 2).

Table 2. Breakdown of Programs by Field of Study

\begin{tabular}{lcc}
\hline \multicolumn{1}{c}{ Field } & $\begin{array}{c}\text { \# Of Program } \\
\text { by Field }\end{array}$ & $\begin{array}{c}\text { \% Representation } \\
\text { in HE Landscape }\end{array}$ \\
\hline 1. STEM & 492 & 61.2 \\
2. Business Programs & 199 & 24.78 \\
$\begin{array}{l}\text { 3. Social Sciences } \\
\begin{array}{l}\text { Arts \& Humanities } \\
\text { (SSAH) }\end{array}\end{array}$ & 112 & 13.95 \\
\hline \multicolumn{1}{c}{ Total } & $\mathbf{8 0 3}$ & $\mathbf{1 0 0 \%}$ \\
\hline
\end{tabular}

\subsection{STEM Programs}

In the area of STEM programs, schools Engineering $(33.95 \%)$ programs were the most represented, followed by Life Sciences $(23.18 \%)$, Medical Studies $(22.75 \%)$, and computer science (22.13\%). Table 3 and Figure 1 below show the distribution of degree programs by department of study.

Table 3. STEM Degree Programs by Department

\begin{tabular}{lcc}
\hline $\begin{array}{c}\text { STEM Program } \\
\text { Cluster }\end{array}$ & $\begin{array}{c}\text { \# Of Programs } \\
\text { Per School }\end{array}$ & \% \\
\hline 1. Engineering & 167 & 33.95 \\
2. Life Sciences & 114 & 23.18 \\
3. Medical Studies & 112 & 22.78 \\
4. Computer & 99 & 20.13 \\
Science & $\mathbf{4 9 2}$ & $\mathbf{1 0 0 \%}$ \\
\hline \multicolumn{1}{c}{ Total } &
\end{tabular}

Electrical Engineering, Mechanical Engineering, and Civil Engineering are offered by 31 (67\%), 30 (65\%) and $27(59 \%)$ universities and colleges, respectively. Closely behind follows Architecture 20 (44\%), Control Systems Engineering $16(35 \%)$ and Chemical Engineering 14 (30\%). Interior Design, which is mostly only offered to female students, is taught by $16(35 \%)$ of universities and 
colleges. The next major parts are the Life and Physical Sciences: Mathematics and Physics 21 (46\%), Chemistry $20(44 \%)$ and Biology 18 (39\%). Computer science and related majors constituted $31(67 \%)$ of the institutions, including 29 (63\%) Information Technology and 20 (44\%) Computer Engineering.

In the medical and health programs Nursing was the most popular program with 22 offerings, Clinical Laboratory Instruction (20), Pharmacy (18) and Public Health Information (12). The actual number of degrees offered the medical and health programs nationwide is much higher because specialized medical universities were excluded from our database. Unlike in the SSAH fields, the Saudi government has put more resources to support medical programs to increase the representation of Saudi nationals in the health sector historically run nearly exclusively by foreigners. Alanezi et al. [2] point to the current policy of Saudization as a localization policy aimed at changing this history. The change can only be sustained if it back by tertiary education curricula that matches the market needs. The prioritization of training in this sector is not unconnected to the realization by the government of an emerging health crisis. The country has become one of the top ten countries with the prevalence of diabetes and obesity [19,39].

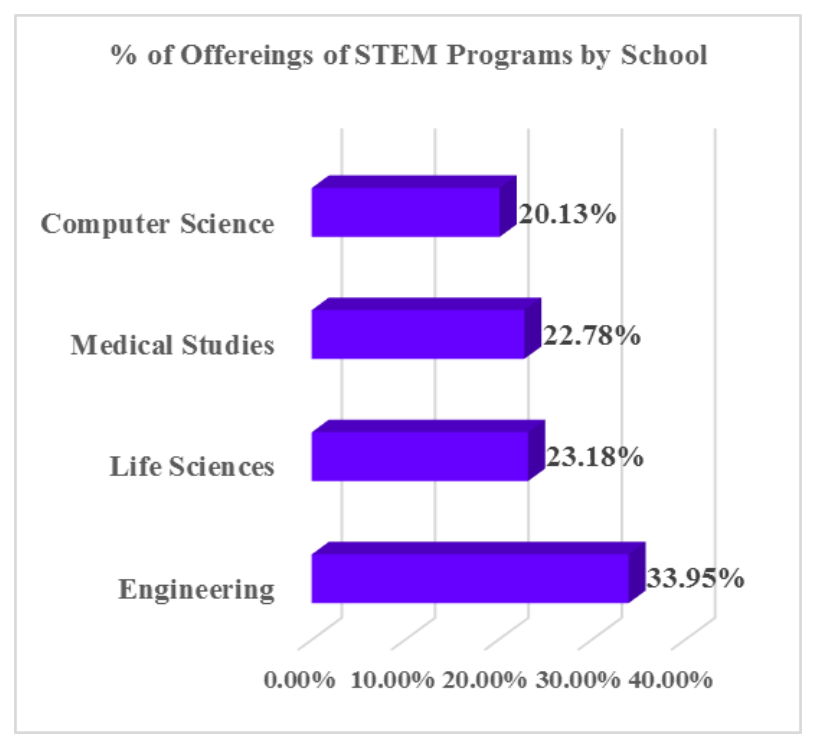

Figure 1. Graph of STEM Degree Program by Department

\subsection{Business Programs}

Business programs were the second most represented cluster of programs in the 46-representative sample of Saudi colleges and universities sampled for this study. About twenty-four percent of the programs sampled were business programs. The most solicited business program was Accounting (18.60\%), followed by Finance (14.57\%), Management Information Systems (12.56\%), Marketing (12.06\%), Management (10.50\%), Business Administration (9.05\%), Human Resources Management
(6.55\%), Home Management (10\%), and Economic $(4.50 \%)$ (see Table 4). The representation of the remaining identified business programs was at $2 \%$ and below.

Table 4. Business Degree Programs

\begin{tabular}{lcc}
\hline \multicolumn{1}{c}{ Program } & \# Of Offerings & \% \\
\hline 1. Accounting & 37 & 18.60 \\
2. Finance & 29 & 14.57 \\
3. Management Info Systems & 25 & 12.56 \\
4. Marketing & 24 & 12.06 \\
5. Management & 20 & 10.5 \\
6. Business Administration & 18 & 9.05 \\
7. Human Resources Mangt. & 13 & 6.55 \\
8. Home Management & 10 & 5.02 \\
9. Economics & 9 & 4.50 \\
10. Public Administration & 4 & 2.01 \\
11. Supply Chain Management & 3 & 1.50 \\
12. Health Administration & 3 & 1.50 \\
13. Public Relations & 2 & 1.00 \\
14. Aviation Management & 1 & 0.5 \\
15. Sports Administration & 1 & 0.5 \\
\hline \multicolumn{1}{c}{ Total } & $\mathbf{1 9 9}$ & $\mathbf{1 0 0 \%}$ \\
\hline
\end{tabular}

There was total of 199 business degree offerings. Business degrees with a strong multidisciplinary component such as Management Information Systems (MIS) were identified as popular. The degree in accounting is offered 37 times in about $80 \%$ of the 46 universities and colleges studied. The representation of business degrees is further illustrated in Figure 2 below.

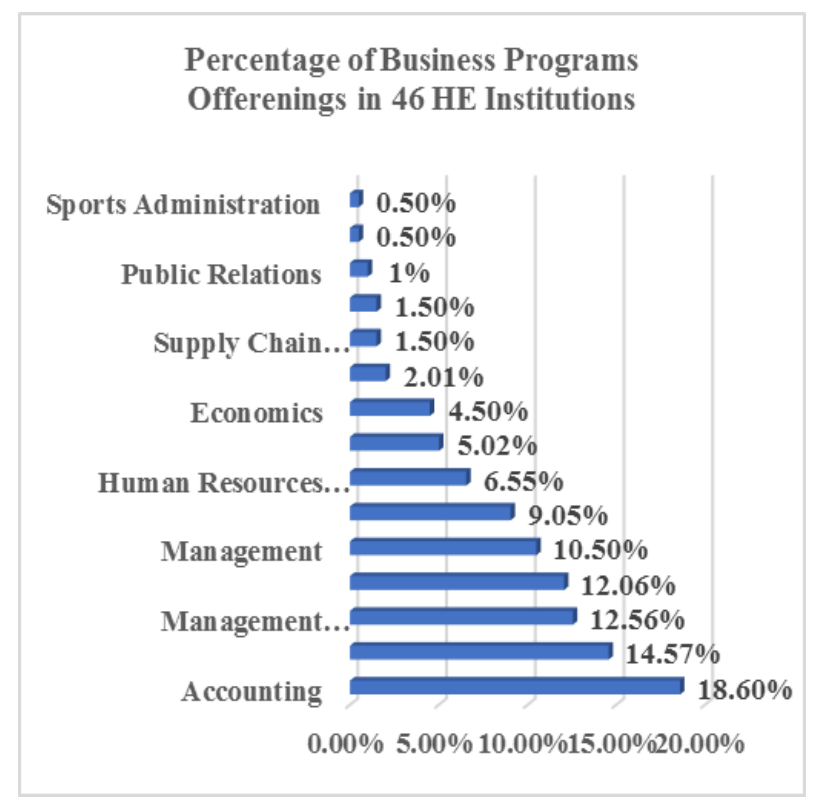

Figure 2. Business Degree Programs 


\subsection{SSAH Programs}

Of all the Social Sciences, Arts, and Humanities (SSAH) programs offered, English was the leading most offered program with 27 offerings (24.11\%), followed by History with 11 offerings $(9.82 \%)$, Psychology with 10 offerings $(8.92 \%)$, and Clothing and Textile Design with 10 offerings $(8.92 \%)$. Sociology, Geography, and Graphic and Digital Design each had 8 offerings, representing 7.15\% of the offerings of SSAH programs. Communication programs represented $6.25 \%$ of the offerings while rest of programs got a representation of between $3.58 \%$ and $0.90 \%$ (see Table 5 and Figure 3).

Table 5. SSAH Degree Program Representation

\begin{tabular}{lcc}
\hline \multicolumn{1}{c}{ Program } & \# Of Offerings & \% \\
\hline 1. English & 27 & 24.11 \\
2. History & 11 & 9.82 \\
3. Psychology & 10 & 8.92 \\
4. Clothing \&Textile Design & 10 & 8.92 \\
5. Sociology & 8 & 7.15 \\
6. Geography & 8 & 7.15 \\
7.Graphic \&Digital Design & 8 & 7.15 \\
8. Communication & 7 & 6.25 \\
9. Tourism & 4 & 3.58 \\
10. Hotel Management & 4 & 3.58 \\
11. French & 3 & 2.68 \\
12. Applied Arts & 3 & 2.68 \\
13. Journalism & 3 & 2.68 \\
14. Library \& Info Systems & 3 & 2.68 \\
15. Linguistics & 2 & 1.79 \\
16. International Relations & 1 & 0.90 \\
\hline \multicolumn{1}{c}{ Total } & $\mathbf{1 1 2}$ & $\mathbf{1 0 0 \%}$ \\
\hline
\end{tabular}

The fact that English is the most offered SSAH program aligns with the trend toward the adoption of English as the main language of instruction in Saudi colleges and universities. This could also be explained by the increase in creation of transition programs in English and Math, designed to prepare high school graduate for college. A lot of these graduates usually have very inadequate knowledge and skills in English and Math necessitating robust remedial preparatory programs aimed at making the students college ready.

The findings also indicate that tourism and hotel management programs represent only about $3.58 \%$ of the SSAH degree offerings. This should be a cause for concern considering the tourism industry would play a crucial role in the diversification of the Saudi economy as stipulated in Vision 2030. Currently, this industry employs a lot of expatriates in these types of jobs which is a missed opportunity since these positions could be filled by Saudis. Government is massively investing in this industry, including the building Neom, an entirely new state-of-the-art city to attract tourists. Training more Saudis to occupy positions in hospitality industry not only promotes economic diversification but make huge dent on the unemployment numbers among Saudi youth, especially women. Since women often work in service oriented, jobs, this may help improve the employment gap for women.

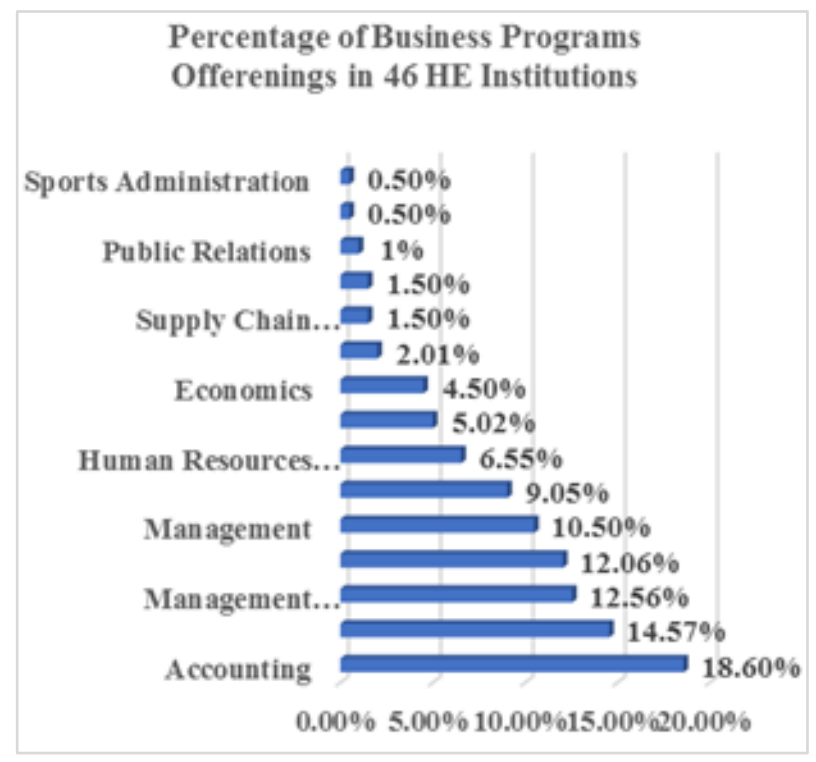

Figure 3. SSAH Degree Program Representation

\subsection{Research Question 1}

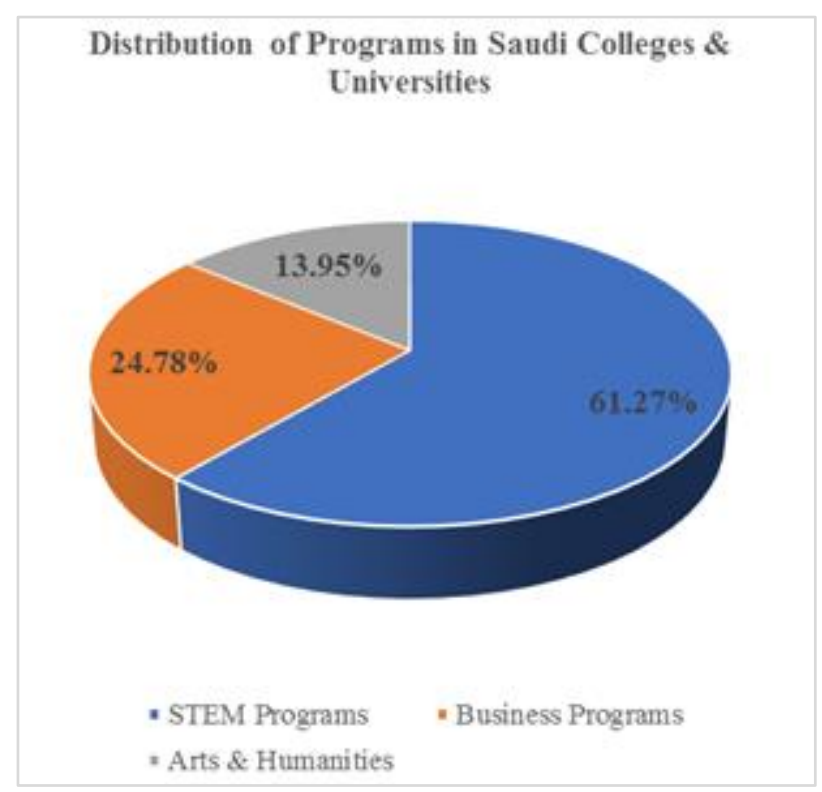

Figure 4. Distribution of Degrees in Saudi HE Institutions

Research question one sought to determine if Social Sciences, Arts, and Humanities (SSAH) are underrepresented in Saudi higher educational institutions. Findings indicated that Saudi HE investments in STEM and Business programs were significantly higher than investments in Arts and Humanities STEM program 
represented $61.27 \%$ of all degree offerings, Business represent $24.78 \%$, and Social Sciences, Arts, and Humanities carried only $13.95 \%$ representation (see Figure 4).

Data indicated that Saudi HE educational institutions demonstrate strong penchant for degrees in STEM and business while in many cases ignoring the possible role of Social Sciences, Arts, and Humanities programs in their economy and society at large. The chart above provides a better picture of the distribution of degree programs in the 46 Saudi universities included in this study.

\subsection{Research Question 2}

Research question number two asked to know whether there was a difference in investment in the SSAH programs between private and public institutions. Public institutions had $81.45 \% \quad(n=654)$ of the programs identified and included in the study while private institutions had $18.56 \%(n=149)$ of the programs. Of the programs identified in public institutions in the three groups (STEM, Business, and Social Sciences, Arts, and Humanities), $64.23 \% \quad(n=420)$ were STEM programs, $21.11 \%(\mathrm{n}=138)$ Business, and $14.68 \%(\mathrm{n}=96 \%)$ Social Sciences, Arts, and Humanities. In contrast, private institutions had $48.33 \%(n=72)$ of the STEM programs, $40.94 \%(n=61)$ of Business programs, and $10.74 \%(n=16)$ of Social Sciences, Arts, and Humanities programs. Table 6 and Figure 5 below show a breakdown of STEM, business, and SSAH degrees by institution type.

Table 6. Distribution of Degrees by Institution Type

\begin{tabular}{lcccc}
\hline \multicolumn{5}{c}{ Public Vs. Private } \\
\hline & Private & \% & Public & \% \\
\hline 1. STEM & 72 & 48.33 & 420 & 64.23 \\
2. Business & 61 & 40.94 & 138 & 21.11 \\
3.Social Sciences, & 16 & 10.74 & 96 & 14.68 \\
\hline Arts, Humanities & $\mathrm{N}=149$ & 18.56 & $\mathrm{~N}=654$ & 81.45 \\
\hline
\end{tabular}

Findings indicated that private institutions tended to invest significantly less in social sciences, arts, and humanities programs than their public counterparts. Only $10.74 \%$ of programs in private $\mathrm{HE}$ institutions were SSAH while $14.68 \%$ of programs in public institutions were STEM. This finding indicates that private colleges and universities, including recently founded ones, tend are stronger promoters of STEM and Business programs. This explains why about $89 \%$ of programs in private institutions were STEM and business programs combined compared to about $85 \%$ in public colleges and universities.

An interesting unintended finding was that while private institutions were less likely to invest in SSAH programs. They tended to invest significantly more in business programs (40.94\%) than public institutions
(21.11\%).

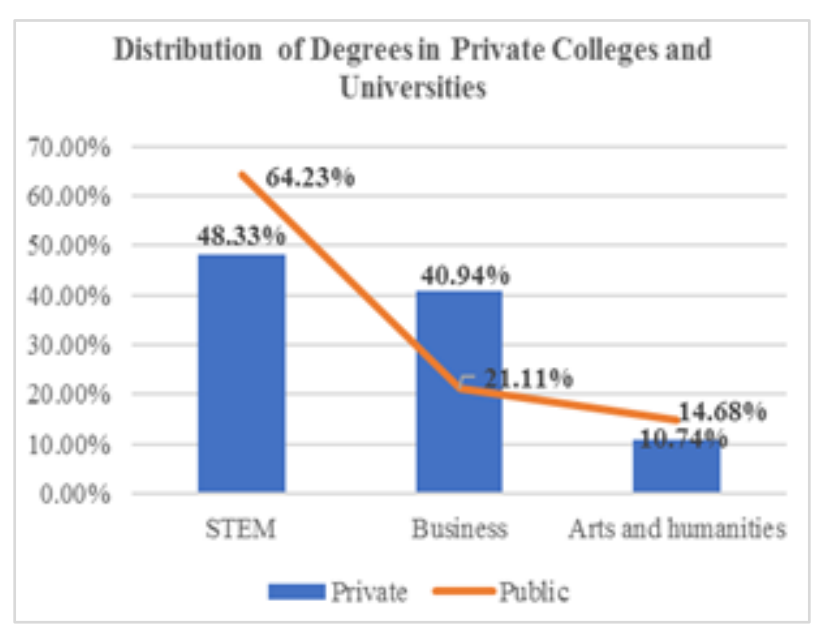

Figure 5. Distribution of Degrees by Institution Type

\subsection{Research Question 3}

Data on the distribution and levels of representation of degrees in Saudi tertiary educational institutions in the three classifications of degrees in this study corroborates the literature on Saudi higher education that socioeconomic and historical factors have a pejorative affect the stakeholders' attitudes towards social sciences Arts and humanities fields. The history and culture of Saudi Arabia are interconnected with its emergence of in the first half of the $20^{\text {th }}$ century as a leading world producer of oil, following the discovery of huge oil reserves in 1933. The influx of wealth through the oil revenue proved to be overwhelming and a new chapter in the life of the country began. Naturally, the higher education system was designed to meet the of the huge petrochemical industry and business. It was considered prestigious for young Saudis to enroll in engineering and business programs and land readily available jobs in the government owned oil company. Higher educational institutions had to be set up to cater for the needs of oil company and its subsidiaries. The trend has continued for about three quarters if a century almost uninterrupted as needs of the Saudi job market have mostly been in fields associated with its humongous petrochemical industry led today by the world's largest oil company, Saudi Aramco. Economic considerations and history have not only raised the prestige associated with STEM and business degrees in Saudi society but has also shaped sociocultural attitudes toward work and employment. Most young Saudi strive to work for the government-owned petrochemical companies, especially Saudi Aramco, not only because they are the biggest employers, but also because it is perceived as prestigious. The National [33] reported that more than $70 \%$ of young Saudis prefer working with the government. These sociocultural and historical factors provide an explanation as to why higher educational institutions 
would neglect opening programs in the social sciences, arts, and humanities. Young Saudis have been conditioned to think that real professional success equates to earning a technical degree that leads to employment in the oil sector. According to Alghamedi [40], this attitude is worsened by the mismatch between market needs and educational outcomes.

While the high value placed on STEM degrees by individuals and families is understandable, it clearly makes it necessary for the country that has the vision of reducing its over-dependence on oil through economic diversification to actively promote mass training of professionals in the social sciences, arts, and humanities. Today's Saudi job market indicates that most engineering slots are already filled, yet the universities continue to mass produce engineers. This is adding to the very high unemployment rate in Saudi Arabia. A 2016 study revealed that $63 \%$ of Saudi graduates thought they would have fared better in the job market if they had chosen a different college major. The Saudi Gazette [30] pointed to the lack of skills as a major barrier in the way of new Saudi graduates landing employment. The study also reported that the lack of essential skills constituted a major obstacle for fresh Saudi graduates to find a job. This report confirmed the existence of another problem created by cultural bias in favor of STEM programs which is massive and unselective enrollment of students in STEM programs even when they could have been more successful in other areas specialization.

\section{Discussion of Findings \& Implications}

The findings irrefutably show that the Saudi higher educational system shows a strong preference for STEM and business programs and a limited interest in programs in the Social Sciences, Arts, and Humanities. This trend, if not revised, can work against the Saudi Vision 2030 goals which emphasize the diversification of the economy to reduce dependency on the oil sector. Enticing more Saudi youth to enter careers in SSAH. would make a difference in government efforts to diversify the economy. Dallal purports that there is a crisis in humanities in the Arab world in general, but the situation is especially pronounced in Saudi Arabia [13].

Critical thinking and philosophy are barely being introduced in Saudi schools. The introduction of these SSAH courses is challenged by the reality that only a few Saudi nationals are qualified to teach-an obvious scarcity considering that the existing HE system has not invested adequately in SSAH disciplines [8]. Another difficulty with the innovations that most Saudi students who have earned degrees abroad specialized in STEM and business programs. Furthermore, teaching has not been culturally perceived as a noble profession [23].

\subsection{Job Market Implications}

There are now more than 1.62 million Saudi students enrolled in higher education institutions with about 130.000 graduating at the end of each academic year [37]. These numbers have increased steadily from previous years as the country's the population continues to grow slowly but steadily.

Habibi [16] warned that Saudi Arabia might be training too many graduates who will not find jobs, especially in the engineering fields which continue to produce the largest number of graduates. This prediction has largely materialized as the unemployment rate in Saudi Arabia has continued to rise in recent years. According to Abdulelah [42], Saudi Arabia is finally starting to face some of its first real challenges of the 21 st century in the form of high rate of unemployment. He argues that one of the most important things the government can do to mitigate the damage to the economy resulting from unemployment is to fasten the implementation of Vision 203 goals by moving the economy from an oil-based to a knowledge -based one. Hvidt [17] perceives similar problems in other GCC countries and advocates for the investment in knowledge-based economies in the entire region. We purport in this study, based on the literature, that one way to endure a sustained and diversified economy is to invest in SSAH programs. Even though market trends have slightly reduced enrollment in engineering, computer science, and business degrees, these programs continue to produce significantly more graduates than needed by job market.

The government's Saudization program (Nitagat), initiated in 2011, has the praiseworthy objective of reducing unemployment by mandating hiring quotas for Saudi nationals in all companies and organization located within the country. The quotas have and will continue to grow as more young Saudis graduate from college. The difficulty with this program is that employers in the SSAH-related jobs such as K-12 and higher education teaching do not find enough qualified Saudis to meet the quota stipulations [27]. According to Saudi News private sector Saudization quotas have risen to $22.75 \%$ [26]. While these mandates make a lot of common sense, they would only be productive if Saudi are trained to occupy the positions in private schools, organizations, and companies. The survival of every private business is dependent on the quality of its workforce. As a result, it is necessary that Saudi colleges and universities as well as students and their families, begin to prioritize SSAH programs that train citizens for jobs in these areas. The researchers worked for than five years for a Saudi higher education institution in the Eastern Province that could hardly respect the Saudization quota of $20 \%$ in its hiring. There are different color codes for compliance with the program and a company that is in code red, with a very low number of Saudi employees, would not receive any government support for foreign worker visas. The ratio of 
nationals to be hired in specific retail stores rose to $70 \%$ in 2018 and was recently raised by the Saudi Labor Ministry to $100 \%$ in the hospitality sector [31].

As economic experts already predicted, the Saudization program has not put any significant dent into the unemployment rate of Saudis but caused a great amount of frustration among private businesses [28]. It did not help that the Saudi Labor Ministry set the minimum wage for Saudis at 5300 Saudi Riyal (SAR) while that of expatriates was set at 2500 SAR. In a context where the productivity of expatriates far exceeds that of Saudis, the decision naturally had the potential of being counterproductive. Also, the decision was not backed with interest by unemployed Saudis who are still attracted to jobs in engineering, computer science, and business. Notwithstanding, the achievement of this goal is compromised by the fact that these programs need students with a strong background in mathematics, in a context where math literacy remains a huge issue.

Employment problems are largely cultural in Saudi Arabia and difficult to fix via government intervention even though the Ministry of Labor and Social Development makes enormous effort to resolve the problem [23]. Young Saudis - especially males-refuse jobs that they consider beneath their dignity. The least jobs they are ready to take in great numbers were security and security guard jobs. Every other job considered to be beneath the bar is handled by a large force of expatriates, mainly from the Philippines, India, Pakistan, Bangladesh, and Nepal.

This review study reveals that one of the main reasons for the current high unemployment rate in Saudi Arabia $(8.22 \%)$ is the lack of diversification in college degrees. The glory years where almost every young Saudi was trained with the sole goal of getting a government job or working for the government-run oil companies are over. Unfortunately, colleges and universities do not seem to be changing with the trend to diversify their degree options by tapping into the Social Sciences, Arts, and Humanities programs. Nonetheless, the awareness and the pinch from unemployment has led to changes attitudes toward certain jobs. Saudis now work in the fast-food business or as taxi drivers but not yet in considerable numbers [15]. To encourage the change of mentality the government founded a widespread network of vocational schools all over Saudi Arabia. Despites this effort, Saudi families apparently still feel the stigma of having their sons and daughters work in professions they consider inferior. They would rather prefer an unemployed son or daughter who graduates from a more reputable STEM program while hoping they would eventually land a decent job at the Saudi Aramco oil company or any of its affiliates [5]. This is an important consideration when it comes to selecting a marriage partner in a country where marriages are still brokered.

Saudi government and the higher education system will still have to figure out how to make professions in arts, humanities, and social sciences attractive to young Saudis. Saudization and Vision 2030 goals in education can only be successful if sociocultural attitudes towards careers that are not linked to the petrochemical industry change significantly [35]. General education programs that have a strong SSAH component and are designed to equip graduates with competencies in communication, critical thinking, and other social skills needed at the workplace are in short supply in the Saudi higher education system. As a result, it is not surprising that the literature underscores that Saudi college graduates have been found to be unqualified and lacking in fundamental employability traits like punctuality, work ethics, reliability, critical thinking, and attention to details [6].

\subsection{Recommendations}

The findings of this study reveal the urgency to prioritize SSAH programs in the Kingdom of Saudi Arabia today. Private colleges and universities can be empowered to play a leading role in the creation of liberal departments and programs. Such an initiatives would be in line with the Ministry of Education bylaw, article 8, which stipulates that private universities' "programs must be in disciplines needed in the labor market" [21]. The phrasing of this policy could prove too restrictive because philosophy, sociology, or history, for example, might not be found on a job posting, apart from a teaching position, but the skills the programs teach such as critical reasoning, interpersonal, communication, and cultural competencies, are needed and sometimes required by people in various professions. Hence the need for the Saudi Ministry of Education to reinterpret the stipulation and systematically promote inclusion SSAH programs in most colleges and universities.

The scarcity of non-STEM degrees limits employment options for young Saudis in the current job market since almost all young college graduates are seeking employment in the crowded field of engineering. The current higher education system in Saudi Arabia suffers from a deficiency of degrees, especially in the field of Social Sciences, Arts, and Humanities. The Millennials and Gen Zs will continue to face rapidly changing and thus require transferable skills that can be flexibly applied. These skills are mainly taught in the humanities and investing in humanities degrees would pay off in the short term. While it is impossible to predict what kind of jobs the market will need in the long term, it would be certainly wise for the government to invest in elastic degrees that cover the most important transferable skills. Because of the shortage of humanities degree programs, the Saudi Arabian job market suffers from an excessive supply of engineering and business graduates, many of whom end up unemployed. Saudi Arabia needs to break open their historically grown undiversified-but 
petrified - degree system to a more modern and diverse system to create a knowledge society holistically prepared for the $21^{\text {st }}$ Century global market.

\section{Conclusions}

The decline in the popularity of SSAH programs is a worldwide trend. Alexander underscores continuous drops in humanities degree offerings in the United States, history leading the pack experiencing a drop of 30\% [4]. Unlike the United and many Western countries, Saudi Arabia is not just experiencing a drop in SSAH degrees; they have never been popular in the kingdom's higher education system. Due to the historical and sociocultural underpinnings of the somewhat condescending attitudes towards programs in the social sciences, arts, and humanities, higher educational institutions find it difficult to promote degrees in these fields. The limited SSAH degree choices are not only due to the students' preferences but also because of the HE institutional culture of prioritizing some STEM programs that have traditionally attracted young Saudi students.

The social science, arts, and humanities (SSAH) are invaluable for any knowledge society as they teach transferable skills and open-mindedness as well as indispensable communication, critical thinking, and critical research skills. These are essential for the $21^{\text {st }}$-century job market and especially for a job market that is in transformation and requires enormous privatization as does the Saudi job market. While well-established economies experience the rise and fall of the humanities in undergraduate education, an emerging economy like Saudi Arabia must endeavor to experience its own rise. Though much research and government statistics lament over the drop in humanities degrees in the United States, there is no shortage of professionals in the humanities [25]. This is mostly because of the huge numbers of existing graduates and the extensive higher education landscape that has seen an increase in humanities associate degrees even as bachelor's degrees continue to decline $[1,5]$. This has never been the experience of Saudi Arabia, hence the need for the country's HE system to make first-time significant investments in degrees in social sciences, arts, and humanities in a sustained effort build a knowledge-based diversified economy.

\section{REFERENCES}

[1] Association of American Colleges \& Universities, "The Rise and Fall of the Humanities in Undergraduate Education," Insights and Campus Innovations in Liberal Education, 2017. https://www.aacu.org/aacu-news/newslet ter/2017/august/facts-figures [Accessed: June 1, 2021]
[2] Alanezi A., Darwish T., Singh S., Miroux A., "Substituting expats with locals: TNCs and the indigenization policies of Saudi Arabia," Transnational Corporations, vol. 27, no. 1, pp. 63-86, 2020. DOI:https://doi.org/10.18356/41c3a7d3-e $\mathrm{n}$

[3] Arab News, "80\% Saudis prefer government jobs," 2016. https://www.arabnews.com/node/932356/saudi-arabia.[Ac cessed Sept. 12, 2020].

[4] Alexander B., "The humanities keep declining: the case of history," Academic Next, Nov. 2018. https://bryanalexand er.org/enrollment/the-humanities-keep-declining-the-caseof-history/

[5] Al-Huwairni R., "Do you need a college degree to find a job?," Saudi Gazette, 2017. https://saudigazette.com.sa/arti cle/170496

[6] Al-Jumaiah A., Saudi Graduates lack Job Market Skills," Saudi Gazette, 2018. http://saudigazette.com.sa/article/527 932/Opinion/Local-Viewpoint/Saudi-graduates-lack-job-m arket-skills

[7] Al-Saraj T., "Teaching philosophy in the Saudi education system," Araba News, 2019. https://www.arabnews.com/n ode/1440846

[8] Al-Saraj T., "Teacher certification in Saudi Arabia key to raising education standards," Araba News, 2019. http://www.arabnews.com/node/1527316. [Accessed June. $11,2020]$.

[9] Alamri A., "Higher Education in Saudi Arabia," Journal of Higher Education Theory and Practice, vol. 11, no. 4, 2011.

[10] AlMunajjed M., "Women's Education in Saudi Arabia-The Way Forward," 2009.http://arabdevelopmentportal.com/sit es/default/files/publication/211.womens_education_in_sau di_arabia_the_way_forward.pdf

[11] Cernigoi A., "Saudi venture looks to education to help fix youth unemployment woes," Philanthropy Age, 2017. https://www.philanthropyage.com/education/education-cou ld-help-fix-saudi-youth-unemployment-woes

[12] Clark N., "Education in Saudi Arabia," World Education News \& Reviews, 2018. https://wenr.wes.org/2014/11/hig her-education-in-saudi-arabia

[13] Dallal, A., "The crisis of the academic humanities in the Arab World," Comparative Studies of South Asia, Africa and the Middle East, vol. 37, no. 1, pp. 134, 2017.

[14] Euchi J., Omri A., Al-Tit A., "The pillars of economic diversification in Saudi Arabia," World Review of Science Technology and Sustainable Development, 2018. DOI:10.1504/WRSTSD.2018.095719

[15] Financial Tribune, "Saudis swallow pride embrace lowly jobs," World Economy, vol. 14, no. 4, 2018. https://financialtribune.com/node/90940

[16] Habibi N., "Is Saudi Arabia training too many graduates?," University World News, 2015. University World News. https://www.universityworldnews.com/post.php?story=201 50714013422488

[17] Hvidt M., "Transformation of the Arab Gulf economies into knowledge economies: Motivational issues related to 
the tertiary education sector," Arab Center for Research \& Policy Studies, pp. 1-28, 2015. http://www.jstor.com/stable/resrep12705

[18] Jacobs J., Worth J., "The evolving mission of workforce development in the community college", Community College Research Center, Political Science, Sociology, 2019. https://ccrc.tc.columbia.edu/publications/evolving-m ission-workforce-development-community-college.html

[19] Al-Hazzaa M., "The public health burden of physical inactivity in Saudi Arabia," Journal of Family and Community Medicine, vol. 11, no. 2, p. 45, 2014. https://www.ncbi.nlm.nih.gov/pmc/articles/PMC3410089

[20] MidEast Posts/The Voices of the Middle East, "Saudi universities producing 'unemployable' graduates," 2012. http://mideastposts.com/middle-east-society/saudi-universi ties-producing-unemployable-graduates/

[21] Ministry of Education Saudi Arabia, "S. A. bylaws for private universities," [n.d.] https://www.moe.gov.sa/en/Hig herEducation/PrivateHigherEducation/RulesAndRegulatio ns/Pages/Bylaws-PrivateUniversities.aspx.

[22] Ministry of Education Saudi Arabia, "Higher education statistics," 2016. https://departments.moe.gov.sa/Planning Development/RelatedDepartments/Educationstatisticscente r/EducationDetailedReports/Docs/Table7-01_37-38.html

[23] Ministry of Labor and Social Development, (2016). "Saudi Arabia labor market report," 2016. file:///D:/Jorg/G20\%20 Labor\%20Market\%20Report\%202016\%20-\%20Final\%20\%20Low\%20res.pdf.

[24] National Science Foundation, "What is STEM education," Sept. 2017. Available: https://www.nsf.gov/news/news_su mm.jsp?cntn_id=243502 [Accessed May 5, 2020].

[25] NCES/ IPEDS, "2017-18 Integrated postsecondary education data system (IPEDS) methodology Report," 2018. Available: https://nces.ed.gov/pubs2018/2018195.pd $\mathrm{f}$

[26] Obaid R., "Private sector Saudization rate rises to 22.75 percent in 2021," Arab News, 2021. https://www.arabnews .com/node/1850681/business-economy

[27] Peck J., "Can Hiring Quotas Work? The Effect of the Nitaqat Program on the Saudi Private Sector," Massachusetts Institute of Technology, 2014. http://economics.mit.edu/files/9417

[28] Rohstock A., "The History of Higher Education," The Future of Education Research, vol 1, 2011. https://doi.org/10.1007/978-94-6091-827-8_7

[29] Saleh M. A., "Development of higher education in Saudi Arabia," High Educ, vol. 15, p. 17, 1986. https://doi.org/10

\section{$.1007 / \mathrm{BF} 00138089$}

[30] Saudi Gazette. "Lack of skills' major barrier for new Saudi graduates to find jobs," NewsPress, 2016. http://saudigazette.com.sa/article/160092

[31] Saudi Gazette, "Labor Ministry: 100\% Saudization of 20 hospitality jobs as of next year," NewsPress, 2019. http://www.saudigazette.com.sa/article/573105/SAUDI-A RABIA/Labor-Ministry-100-Saudization-of-20-hospitality -jobs-as-of-next-year

[32] Selingo J., "As Humanities Majors Decline, Colleges Try to Hype Up Their Programs," The Atlantic, 2018. https://www.naicu.edu/news-events/headline-news/2018/1 1/as-humanities-majors-decline,-colleges-try-to-hype.

[33] The National, "Survey shows $70 \%$ of GCC youth prefer government jobs," 2016. https://www.thenational.ae/uae/g overnment/survey-shows-70-of-gcc-youth-prefer-governm ent-jobs-1.162857

[34] UNESCO, "International Standard Classification of Education," UNESCO Institute of Statistics, 2015. http://dx.doi.org/10.15220/978-92-9189-179-5-en2015.

[35] Vision 2030, "Vision Realization Programs Document," 2016. https://vision2030.gov.sa/en [Accessed March 15, 2020]

[36] Weinberger A., Nistor N., "Culture, profession, and attitudes towards educational technology: A large-scale, German-Romanian study" Universität des Saarlandes, 2010. https://dl.acm.org/doi/10.1145/1841853.1841886

[37] World Education Services, "Education in Saudi Arabia," World Education News \& Reviews, 2020. https://wenr.wes.org/2020/04/education-in-saudi-arabia

[38] Word Bank/ILO, "Unemployment, total (\% of total labor force) (modeled ILO estimate) Saudi Arabia," ILOSTAT Data Base, 2021. https://data.worldbank.org/indicator/SL. UEM.TOTL.ZS?locations=SA

[39] Estimo R., "Sedentary lifestyle, unhealthy diet identified as major causes of diabetes in Saudi Arabia," Arab News, 2017. http://www.arabnews.com/node/1196261/saudi-arab ia

[40] Alghamedi A., "Enhancing employment opportunities in the Saudi Arabian private," Pepperdine University, 2016. https://digitalcommons.pepperdine.edu/etd/752

[41] Al-Rasheed M., "A history of Saudi Arabia," Cambridge University Press, 2012. DOI: https://doi.org/10.1017/CBO 9780511993510

[42] Abdulelah A., "The cost of unemployment in Saudi Arabia," International Journal of Economics and Finance, vol. 11, no. 11, 2019. DOI:10.5539/ijef.v11n11p30 